\title{
Phacoemulsification in eyes with cataract and high myopia
}

\section{Facoemulsificação em olhos com catarata e alta miopia}

\author{
Servet Cetinkaya ${ }^{1}$, Nursen Oncel Acir ${ }^{2}$, Yasemin Fatma Cetinkaya ${ }^{3}$, Zeynep Dadacl ${ }^{2}$, Halil İ Irrahim Yener $^{4}$, Faik Saglam ${ }^{5}$
}

\begin{abstract}
Purpose: To evaluate the outcomes and complications following phacoemulsification surgery in eyes with cataract and high myopia.

Methods: We retrospectively evaluated the data of 43 eyes of 28 consecutive patients ( 12 males, 16 females) with cataract and high myopia who had undergone phacoemulsification and intraocular lens (IOL) implantation. The mean [ \pm standard deviation (range)] age of the patients was $59.20 \pm 11.08$ (39-77) years.

Results: The frequency of nuclear cataract was significantly higher than that of other cataract types $(P=0.003)$. The mean axial length was $28.97 \pm 1.99(26-33) \mathrm{mm}$ and the mean IOL power was $5.09 \pm 4.78(-3.0$ to +14.0$)$ diopters (D). The mean preoperative spherical equivalent (SE) was $-16.48 \pm 5.23(-8.00$ to -25.00$) D$ and the mean postoperative SE was $-1.46 \pm 0.93(0.00$ to -3.00$) \mathrm{D}(\mathrm{P}=0.00)$. The mean preoperative best-corrected visual acuity (BCVA) was $0.91 \pm 0.37(0.30$ to -1.50$)$ $\log M A R$ and the mean postoperative BCVA was $0.29 \pm 0.25$ (0.00-1.00) logMAR $(\mathrm{P}=0.00)$. Twenty-two eyes $(51.2 \%)$ achieved the target postoperative refraction $( \pm 1.0 \mathrm{D})$. The eyes were divided into 3 groups according to the axial length. The mean biometric error was significantly higher in the group with the greatest axial length than in the other groups $(\mathrm{P}=0.007)$. Preoperative argon laser photocoagulation was performed in 7 eyes $(16 \%)$ on account of retinal tears, retinal holes, or lattice degeneration. Postoperatively, retinal tears developed in 2 eyes $(4 \%)$ and were treated with photocoagulation. One eye (2\%) developed retinal detachment postoperatively, with the patient consequently referred for retinal surgery. Postoperatively, posterior capsule opacities developed in 11 eyes (25\%), with all cases treated by laser capsulotomy.
\end{abstract}

Conclusions: Good postoperative outcomes following phacoemulsification surgery were observed in patients with cataract and high myopia. However, clinicians should be aware of the risk of postoperative retinal tears and rhegmatogenous retinal detachment. Preoperative prophylactic argon laser photocoagulation treatment should be considered where necessary.

Keywords: Cataract;Myopia; Phacoemulsification/adverse effects; Retinal detachment; Visual acuity

\section{RESUMO}

Objetivo: Avaliação dos resultados e complicações associadas à cirurgia de facoemulsificação em olhos com catarata e miopia alta.

Método: Quarenta e três ol hos de 28 pacientes (12 homens, 16 mulheres) consecutivos com catarata e alta miopia, que haviam sido submetidos a facoemulsificação e implante de lentes intraoculares (LIO), foram avaliados retrospectivamente. A idade foi de 59,20 \pm 11,08, (39-77) anos [média \pm desvio padrão, (variação)].

Resultados: A frequência de catarata nuclear foi significativamente maior do que os outros tipos ( $p=0,003)$. O comprimento axial foi $28,97 \pm 1,99,(26-33) \mathrm{mm}$ e o poder da LIO foi 5,09 \pm 4,78, (-3,0 a 14,0) dioptrias (D). O equivalente esférico pré-operatório (SE) foi de -16,48 $\pm 5,23,(-25,00$ a -8,00) D e o SE pós-operatório foi - $1,46 \pm 0,93,(0,00$ $a-3,00) D,(P=0,00)$. A melhor acuidade visual corrigida pré-operatória (BCVA) foi de $0,91 \pm 0,37,(0,30-1,50) \log$ MAR e a BCVA pós-operatória foi de 0,29 $\pm 0,25,(0,00-1,00)$ $\log M A R,(P=0,00)$. Vinte e dois olhos $(51,2 \%)$ estavam dentro de refração alvo pós-operatória $( \pm 1,0 \mathrm{D})$. Os olhos foram divididos em três grupos, de acordo com o comprimento axial. O erro biométrico foi significativamente maior no terceiro grupo, em comparação com os outros grupos $(p=0,007)$. Fotocoagulação pré-operatória por laser de argônio foi realizada em 7 olhos (16\%) devido a roturas retinianas, buracos de retina ou degeneração látice. No pós-operatório, as roturas da retina ocorreram em dois olhos (4\%); tratados com fotocoagulação. Um olho (2\%) desenvolveu descolamento de retina no pós-operatório e foi encaminhado para cirurgia de retina. No pós-operatório, opacidades da cápsula posterior ocorreram em 11 olhos (25\%) e estes foram tratados com capsulotomia a laser.

Conclusões: A cirurgia de facoemulsificação permite bons resultados em pacientes com catarata e miopia alta. No entanto, devemos estar atentos para a possibilidade de roturas da retina pós-operatórias e para o descolamento de retina regmatogênico. Se necessário, devemos usar o tratamento profilático de fotocoagulação a laser antes da cirurgia.

Descritores:Catarataextraction; Miopia/cirurgia; Facoemulsificação/efeitos adversos; Descolamento retiniano; Acuidade visual

\section{INTRODUCTION}

High myopia is a common condition worldwide, defined as an axial length of $\geq 26.0 \mathrm{~mm}$. The frequency of vitreous and retinal degenerations, such as liquefied vitreous, posterior vitreous detachment, lattice degeneration, retinal holes, and retinal tears, is higher in patients with high myopia than in the general population(1). The World Health Organization estimated there were 161 million visually impaired people worldwide in 2002, with cataract accounting for $47.8 \%$ of cases and the incidence of cataract increasing with age. In developing countries, cataracts occur earlier in life and the incidence is higher ${ }^{(2)}$. Highly myopic eyes tend to develop cataracts earlier than normal eyes, with higher prevalences of nuclear and posterior subcapsular cataracts. In a retrospective study, the prevalence of nuclear and posterior subcapsular cataracts were reportedly $25.07 \%$ and $11.82 \%$, respectively, in non-myopic patients and $40.63 \%$ and $26.22 \%$, respectively, in highly myopic patients ${ }^{(3-5)}$. The selection of appropriately powered intraocular lens $(\mathrm{IOL})$ implants is critical in maintaining good visual quality ${ }^{(6)}$

Both cataract surgery and high myopia increase the risk of postoperative rhegmatogenous retinal detachment (RRD), which originates from retinal holes, tears, or breaks. The degree of myopia, axial length, intraoperative posterior capsule rupture, vitreous loss, and
Submitted for publication: November 26, 2014

Accepted for publication: June 1, 2015

Ophthalmology Clinics, Turkish Red Crescent Hospital, Konya, Turkey.

Department of Ophthalmology, Mevlana University, Faculty of Medicine, Konya, Turkey.

3 Ophthalmology Clinics, Ataturk Training and Research Hospital, Ankara, Turkey.

${ }^{4}$ Konya Eye Centre Hospital, Konya, Turkey.

${ }^{5}$ Department of Ophthalmology, Meram Training and Research Hospital, Konya, Turkey.
Funding: No specific financial support was available for this study.

Disclosure of potential conflicts of interest: None of the authors have any potential conflict of interest to disclose.

Corresponding author: Servet Cetinkaya. Turkish Red Crescent Hospital (Kizilay Hastanesi). Ophthalmology Clinics, Sukran Mah - Taskapu Medrese Sok, № 15 - Meram, Konya - 42200 - Turkey

E-mail: drservet42@gmail.com 
postoperative Nd:YAG laser capsulotomy applications have all been shown to increase the risk of $\mathrm{RRD}^{(7)}$.

In this study, we evaluated the outcomes and complications following phacoemulsification surgery in eyes with cataracts and high myopia.

\section{METHODS}

The study protocol was approved by the local ethics committee. Informed consent was obtained from all study participants. This study was performed in accordance with the tenets of the Declaration of Helsinki.

In this study, we retrospectively evaluated the data of 43 eyes of 28 consecutive patients with cataract and high myopia (12 males, 16 females) who underwent operative interventions between February 2008 and December 2011. Patients with any systemic or ocular disease other than high myopia that may influence visual acuity, intraoperative complications, or retinal detachment were excluded.

Preoperative and postoperative uncorrected visual acuity (UCVA) and best-corrected visual acuity (BCVA) were measured. Preoperative and postoperative refractive values were measured as spherical equivalent (SE), calculated as the summation of the spherical refractive value and half of the cylindrical value. Axial length measurements were performed using an IOL Master Optical Biometer (Carl Zeiss Meditec AG, Jena, Germany). The SRK/T formula was used for IOL power calculations. Fundus examinations were performed preoperatively. Prophylactic argon laser photocoagulation was performed in 3 eyes diagnosed with retinal tears, 2 eyes with retinal holes, and 2 eyes with lattice degeneration.

Target postoperative refractions were within \pm 1.00 diopters (D). Twenty-one patients (75\%) requested mild myopia postoperatively to maintain a near-sighted lifestyle. However, we predominantly aimed for postoperative emmetropia as myopia may continue to increase in later life.

Each operation was performed by a single surgeon (SC). Under subtenon anesthesia, a 2.8-mm clear corneal incision was made superotemporally with a steel blade. The anterior chamber was then filled with a dispersive (Hydroxypropylmethylcellulose, Easy Visc, Germany) viscoelastic material. After continuous curvilinear capsulorhexis, hydrodissection and hydrodelineation were performed. Then, a sideport entrance was created with a 19-gauge microvitreoretinal (MVR) knife. The lens nucleus was removed using the "stop and chop" technique (Sovereign Compact, Phacoemulsification System, AMO, USA). Subsequently, the cortex was aspirated with coaxial irrigation/ aspiration. The capsular bag was filled with a cohesive (Na Hyaluranate 1.6, Easyluron, Germany) viscoelastic material before a foldable monofocal posterior chamber IOL (Acriva, VSY, Turkey) was implanted in the capsular bag through an injector system. The viscoelastic material was then aspirated completely. The entrances were closed with stromal hydration, and finally, intracameral moxifloxacin was administered for postoperative endophthalmitis prophylaxis. Topical antibiotics 4 times a day, and topical steroids 6 times a day were administered for 1 week postoperatively. Topical steroid doses were then tapered over the subsequent 3 weeks.

Data are presented as mean \pm standard deviation. The statistical significance of differences in categorical data and continuous parameters were tested using the chi-square test, paired t-test, and Kruskal-Wallis test. All statistical analyses were performed using commercially available statistical software (SPSS version 22, SPSS, Inc., Chicago, IL). Statistical significance was defined as $P<0.05$.

\section{RESULTS}

Results are presented as [mean \pm standard deviation (range)]. Out of the 28 patients included in this study, 12 (42.8\%) were male and 16 (57.2\%) were female. Fifteen (53.6\%) patients had bilateral cataracts and $13(46.4 \%)$ had unilateral cataracts. The age of the patients was $59.20 \pm 11.08$ (39-77) years. Twenty-five eyes (58.2\%) had nuclear cataracts, 9 eyes (20.9\%) had cortical cataracts, and 9 eyes (20.9\%) had posterior subcapsular cataracts. The frequency of nuclear cataracts was significantly higher than that of other cataract types ( $P=0.003)$.

Axial length was $28.97 \pm 1.99$ (26-33) $\mathrm{mm}$ and IOL power was 5.09 $\pm 4.78(-3.0$ to +14.0$)$ D.

Preoperative SE $[-16.48 \pm 5.23(-8.00$ to -25.00$)$ D] was significantly higher than the postoperative SE $[-1.46 \pm 0.93(0.00$ to -3.00$) \mathrm{D} ; \mathrm{P}=0.00]$. Preoperative BCVA [0.91 \pm 0.37 (0.30-1.50) logMAR] was significantly lower than the postoperative BCVA [0.29 \pm 0.25 (0.00-1.00) logMAR; $\mathrm{P}=0.00]$. Preoperative and postoperative findings are summarized in table 1.

Postoperative follow-up period was $24.44 \pm 1.93$ (21-28) months. Twenty-two eyes (51.2\%) achieved the target postoperative refraction $( \pm 1.0 \mathrm{D})$. Thirty-seven eyes $(86 \%)$ had refraction within the range of 0.00 to $-2.00 \mathrm{D}$. The eyes were divided into 3 groups according to the axial length. The first group comprised 12 eyes with axial lengths between 26 and $28 \mathrm{~mm}$, the second group comprised 14 eyes with axial lengths between 28 and $30 \mathrm{~mm}$, and the third group comprised 17 eyes with axial lengths between 30 and $33 \mathrm{~mm}$. The mean expected refraction was $-0.75 \pm 0.33(0.00$ to -1.00$) \mathrm{D}$ in Group $1,-0.28 \pm$ 0.32 (0.00 to -1.00$) \mathrm{D}$ in $\backslash$ Group 2, and $+0.85 \pm 0.23(+0.50$ to +1.00$) \mathrm{D}$ in Group 3. The mean obtained postoperative refraction was $-1.66 \pm$ 0.88 (0.00 to -3.00) D in Group 1, - $1.35 \pm 1.00$ (0.00 to -3.00) D in Group 2 , and $-1.41 \pm 0.93(0.00$ to -3.00$) \mathrm{D}$ in Group 3 (Table 2). The mean biometric error was $-0.91 \pm 0.84$ (0.00 to -2.50$)$ D in Group 1, - $1.21 \pm$ 0.77 (0.00 to -2.50$)$ D in Group 2, and $-2.14 \pm 1.27(+0.50$ to -4.00$) D$ in Group 3 (Figure 1). The mean biometric error was significantly higher in the third group than in the other groups $(P=0.007)$.

Preoperative prophylactic argon laser photocoagulation was performed in 7 eyes (16\%) on account of retinal tears, retinal holes, and lattice degeneration. No postoperative retinal complications were observed following preoperative prophylactic argon laser photocoagulation. Retinal tears developed in 2 eyes (4\%) 2 and 4 months postoperatively and were treated with argon laser photocoagulation. One eye (2\%) developed retinal detachment (RD) 3 months

Table 1. Preoperative and postoperative findings

\begin{tabular}{|c|c|c|}
\hline Characteristics & $\begin{array}{c}\text { Number, percentage, } \\
\text { mean }( \pm \text { SD) }\end{array}$ & Range \\
\hline \multicolumn{3}{|l|}{ Sex } \\
\hline Male & $12(42.8 \%)$ & \\
\hline Female & $16(57.2 \%)$ & \\
\hline Age (years) & $59.20 \pm 11.08$ & 39 to 77 \\
\hline \multicolumn{3}{|l|}{ Laterality } \\
\hline Unilateral & $13(46.4 \%)$ & \\
\hline Bilateral & $15(53.6 \%)$ & \\
\hline \multicolumn{3}{|l|}{ Type of cataract } \\
\hline Nuclear & $25(58.2 \%)$ & \\
\hline Cortical & $9(20.9 \%)$ & \\
\hline Subcapsular & $9(20.9 \%)$ & \\
\hline Axial length (mm) & $28.97 \pm 1.99$ & 26 to 33 \\
\hline IOL power (D) & $5.09 \pm 4.78$ & -3.00 to +14.00 \\
\hline Pre spherical equivalent (D) & $-16.48 \pm 5.23$ & -8.00 to -25.00 \\
\hline Post spherical equivalent (D) & $-1.46 \pm 0.93$ & 0.00 to -3.00 \\
\hline Pre BCVA (logMAR) & $0.91 \pm 0.37$ & 0.30 to 1.50 \\
\hline Post BCVA (logMAR) & $0.29 \pm 0.25$ & 0.00 to 1.00 \\
\hline
\end{tabular}

$\mathrm{SD}=$ standard deviation; $\mathrm{IOL}=$ intraocular lens; $\mathrm{BCVA}=$ best-corrected visual acuity; Pre $=$ preoperative; Post $=$ postoperative . 
Table 2. Mean expected and achieved ocular postoperative refraction

\begin{tabular}{lccc}
\hline Groups & $\begin{array}{c}\text { Preoperative axial } \\
\text { lenght range }\end{array}$ & $\begin{array}{c}\text { Expected postoperative spherical equivalent } \\
\text { (Mean } \pm \text { SD) }\end{array}$ & $\begin{array}{c}\text { Achieved postoperative spherical equivalent } \\
\text { (Mean } \pm \text { SD) }\end{array}$ \\
\hline Group 1 & 26 to $28 \mathrm{mmHg}$ & $-0.75 \pm 0.33 \mathrm{D}$ & $-1.66 \pm 0.88 \mathrm{D}$ \\
Group 2 & 28 to $30 \mathrm{mmHg}$ & $-0.28 \pm 0.32 \mathrm{D}$ & $-1.35 \pm 1.00 \mathrm{D}$ \\
Group 3 & 30 to $33 \mathrm{mmHg}$ & $+0.85 \pm 0.23 \mathrm{D}$ & $-1.41 \pm 0.93 \mathrm{D}$ \\
\hline
\end{tabular}

$\mathrm{SD}=$ standard deviation

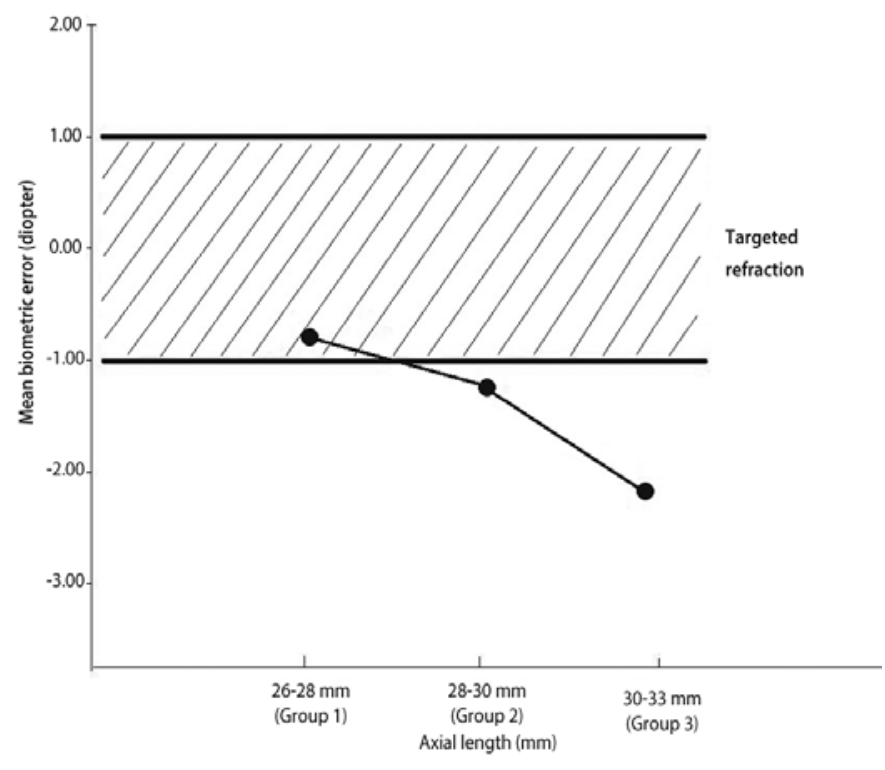

Figure 1. Mean biometric error according to the axial length.

postoperatively and the patient was referred to another center for retinal surgery. Nd:YAG laser capsulotomy was performed in 11 (25\%) eyes that developed posterior capsular opacity between 6 and 18 months postoperatively. No further postoperative complications were observed following argon laser photocoagulation or Nd:YAG laser capsulotomy during further follow-up periods. We were unable to obtain satisfactory postoperative visual outcomes due to myopic retinal degeneration in 12 eyes of 8 patients (27.9\%)

\section{DISCUSSION}

Nuclear subcapsular cataracts are known to be more predominant in highly myopic eyes ${ }^{(4,5,8)}$. In our study, the frequency of nuclear cataracts was significantly higher than that of other types of cataract.

Non-contact optical biometry using partial coherence laser interferometry (IOL Master) provides more accurate and reliable measurements of postoperative refraction compared with conventional applanation ultrasound techniques ${ }^{(9)}$. However, IOL Master measurements are affected by pupil dilation, fixation instability due to macular degeneration, and causes of media opacity, such as corneal scars, dense cataracts, or vitreous hemorrhage ${ }^{(9,10)}$, all of which may cause biometric errors.

Calculation of the IOL power is critical in obtaining good visual outcomes. Presence of posterior staphyloma may cause errors in the measurement of the axial length. Older individuals with posterior staphyloma are more susceptible to larger increases in the axial length, with studies suggesting that B-scan ultrasonography should be performed in these patients to avoid errors in axial length measurement ${ }^{(6,11)}$. The increase in the hyperopic refractive error with the axial length results from the use of positive power IOL constants for both positive and negative power IOLs; therefore, optimization of IOL constants improves the accuracy of IOL power calculations ${ }^{(6,12,13)}$. The SRK/T formula has been found to be more accurate than other formulas in determining the IOL power in highly myopic eyes. However, the Haigis formula has been shown to be the most accurate method for determining the IOL power in eyes with extremely long axial lengths $s^{(12,14,15)}$.

The SRK/T formula was used to determine the IOL power in the present study. We were unable to determine the definite causes of biometric error in our patients. Pupils were undilated during measurements, no patients had mature cataracts, and no patients had corneal scars or vitreous hemorrhage as patients with these disorders were excluded from the study. The biometric errors observed in the present study may be due to the formula used, because we did not optimize the constants and due to fixation instability resulting from myopic macular degeneration. In addition, preoperative corneal astigmatism may have affected the postoperative refraction despite the low rate of preoperative corneal astigmatism observed in the present study. Hyperopic errors are generally observed in patients with long axial lengths (more than $30 \mathrm{~mm}$ ); however, in our study, we observed similar myopic errors in patients with long axial lengths compared with the other 2 groups, with a statistically higher mean biometric error in patients with long axial lengths compared with the other groups.

Mild postoperative myopia is generally recommended for cataract patients with high myopia. Patients usually request mild postoperative myopia as they prefer to see near objects more clearly ${ }^{(16)}$. In the present study, the majority of the patients (75\%) requested mild postoperative myopia. However, axial length may continue to increase with age in patients with high myopia, resulting in greater degrees of myopia with increasing age ${ }^{(11)}$. Therefore, postoperative targeting of emmetropia may be more appropriate, particularly in younger cases. However, patient preference should always be taken into account. In addition, multifocal IOL may provide an alternate option in such patients, provided myopic macular degeneration is not severe.

A number of risk factors for RRD following cataract surgery have been identified, including male sex, young age, race, increased axial length, history of RD, non-intact posterior capsule, vitreous loss, vitreoretinal degenerations, and postoperative Nd:YAG laser capsulotomy ${ }^{(17-19)}$. High myopia is the greatest risk factor for postoperative $\mathrm{RRD}^{(13,20,21)}$. Intraoperative maintenance of an intact posterior capsule, IOL implantation, and anterior vitrectomy in cases of posterior capsular rupture are known to protect against $\mathrm{RRD}^{(22)}$. It has been reported that the increased risk of RRD following cataract extraction may last for up to 2 decades following surgery ${ }^{(23)}$. However, occurrence of RRD years after cataract surgery may be related to the natural history of myopia rather than pseudophakia.

$\mathrm{Nd}$ :YAG laser capsulotomy increases the risk of RRD owing to rupture of the anterior hyaloid membrane, liquid leakage from the anterior chamber, and vitreoretinal traction ${ }^{(24)}$. In our study, 2 eyes developed retinal tears postoperatively and were treated with argon laser photocoagulation. Only 1 eye developed RD and the patient was referred to another hospital for retinal surgery. No patients developed RD following Nd:YAG laser capsulotomy. 
Prophylactic treatment with argon laser photocoagulation for retinal pathologies prior to surgery is protective against RRD. However, retinal tears and RD can occur in previously normal retinal areas or at the edge of photocoagulation scars ${ }^{(7)}$. The findings of the present study corroborate these previous results.

In conclusion, phacoemulsification surgery is associated with positive outcomes in patients with cataract and high myopia. However, the risk of postoperative retinal tears and RRD should be considered with prophylactic argon laser photocoagulation treatment used preoperatively where necessary.

\section{REFERENCES}

1. Hyman L. Myopic and hyperopic refractive error in adults: an overview. Ophthalmic Epidemiol. 2007;14(4):192-7.

2. Wevill M. Epidemiology, Pathophysiology, Causes, Morphology, and Visual Effects of Cataract. In: Yanoff M, Duker JS. Ophthalmology, Fourth Edition. Elsevier Inc. 2014 p.412-418.

3. Jeon S, Kim HS. Clinical characteristics and outcomes of cataract surgery in highly myopic Koreans. Korean J Ophthalmol. 2011;25(2):84-9.

4. Pan CW, Boey PY, Cheng CY, Saw SM, Tay WT, Wang JJ, Tan AG, Mitchell P, Wong TY. Myopia, axial length, and age-related cataract: the Singapore Malay eye study. Invest Ophthalmol Vis Sci. 2013;54(7):4498-502

5. Kanthan GL, Mitchell P, Rochtchina E, Cumming RG, Wang JJ. Myopia and the long-term incidence of cataract and cataract surgery: the Blue Mountains Eye Study. Clin Experiment Ophthalmol. 2014;42(4):347-53.

6. Yokoi T, Moriyama M, Hayashi K, Shimada N, Ohno-Matsui K. Evaluation of refractive error after cataract surgery in highly myopic eyes. Int Ophthalmol. 2013;33(4):343-8.

7. Williams MA, McGimpsey S, Abugreen S, Chan W, Sharkey JA, Best RM, Johnston PB. The incidence and rate of rhegmatogenous retinal detachment seven years after cataract surgery in patients with high myopia. Ulster Med J. 2009:78(2):99-104.

8. Praveen MR, Vasavada AR, Jani UD, Trivedi RH, Choudhary PK. Prevalence of cataract type in relation to axial length in subjects with high myopia and emmetropia in an Indian population. Am J Ophthalmol. 2008;145(1):176-81.

9. Rajan MS, Keilhorn I, Bell JA. Partial coherence laser interferometry vs conventiona ultrasound biometry in intraocular lens power calculations. Eye. 2002:16(5):552-6.

10. Rodriguez-Raton A, Jimenez-Alvarez M, Arteche-Limousin L, Mediavilla-Pena $E$ Larrucea-Martinez I. Effect of pupil dilation on biometry measurements with partia coherence interferometry and its effect on IOL power formula calculation. Eur J Ophthalmol. 2015:25(4):309-14.
11. Saka N, Ohno-Matsui K, Shimada N, Sueyoshi S, Nagaoka N, Hayashi W, Hayashi K, Moriyama M, Kojima A, Yasuzumi K, Yoshida T, Tokoro T, Mochizuki M. Long-term changes in axial length in adult eyes with pathologic myopia. Am J Ophthalmol. 2010; 150(4):562-8.

12. Terzi $E$, Wang $L$, Kohnen T. Accuracy of modern intraocular lens power calculation formulas in refractive lens exchange for high myopia and hyperopia. J Cataract Refract Surg. 2009;35(7):1181-9.

13. Zuberbuhler B, Seyedian M, Tuft S. Phacoemulsification in eyes with extreme axial myopia. J Cataract Refract Surg. 2009;35(2):335-40.

14. Roessler GF, Dietlein TS, Plange N, Roepke AK, Dinslage S, Walter P, Mazinani BA. Accuracy of intraocular lens power calculation using partial coherence inferometry in patients with high myopia. Ophthalmic Physiol Opt. 2012;32(3):228-33.

15. Bang S, Edell E, Yu Q, Pratzer K StarkW. Accuracy of intraocular lens calculations using the IOL Master in eyes with long axial length and a comparison of various formulas. Ophthalmology. 2011;118(3):503-6.

16. Hayashi K, Hayashi H. Optimum target refraction for highly and moderately myopic patients after monofocal intraocular lens implantation. J Cataract Refract Surg. 2007; 33(2):240-6.

17. Alio JL, Ruiz-Moreno JM, Shabayek MH, Lugo FL, Abd El Rahman AM. The risk of retinal detachment in high myopia after small incision coaxial phacoemulsification. Am J Ophthalmology. 2007;144(1):93-8.

18. Lin JY, Ho WL, Ger LP, Sheu SJ. Analysis of factors correlated with the development of pseudophakic retinal detachment-a long-term study in a single medical center. Graefes Arch Clin Exp Ophthalmol. 2013;251(2):459-65.

19. Neuhann IM, Neuhann TF, Heimann H, Schmickler S, Gerl RH, Foerster MH. Retinal detachment after phacoemulsification in high myopia: analysis of 2356 cases. J Cataract Refract Surg. 2008;34(10):1644-57.

20. Al Muammar AR, Al-Harkan D, Al-Rashidy S, Al-Suliman S, Mousa A. Frequency of retinal detachment after cataract surgery in highly myopic patients. Saudi Med J. 2013; 34(5):511-7.

21. Bhagwandien AC, Cheng YY, Wolfs RC, van Meurs JC, Luyten GP. Relationship between retinal detachment and biometry in 4262 cataractous eyes. Ophthalmology. 2006; 113(4):643-9.

22. Singalavanija A, Thongbun O, Tongsai S. Pseudophakic retinal detachment with ruptured posterior lens capsule. J Med Assoc Thai. 2005:88 Suppl 9:S37-42.

23. Erie JC, Raecker MA, Baratz KH, Schleck CD, Burke JP, Robertson DM. Risk of retinal detachment after cataract extraction, 1980-2004: a population-based study. Ophthalmol. 2006:113(11):2026-32.

24. Ozyol E, Ozyol P, Doganay Erdogan B, Onen M. The role of anterior hyaloid face integrity on retinal complications during Nd:YAG laser capsulotomy. Graefes Arch Exp Ophthalmol. 2014;252(1):71-5 